\title{
Amyloidosis Associated to Leishmania Infection in Murine Model
}

\author{
Ana Lucia Abreu-Silva1,2, Gabriel Xavier-Silva ${ }^{1}$, Marlise Neves Milhomem¹, \\ Mylena Andrea Oliveira Torres ${ }^{1}$ and Kátia da Silva Calabrese ${ }^{2}$ \\ ${ }^{1}$ Department of Pathology - Universidade Estadual do Maranhão, São Luís - Maranhão \\ ${ }^{2}$ Laboratory of Imunomodulação and Protozoologia, \\ Instituto Oswaldo Cruz, Rio de Janeiro \\ Brazil
}

\section{Introduction}

Amyloidosis comprises a group of chronic disease characterized by the deposition in different organs of an insoluble and fibrilar protein known as amyloid. AA-amyloidosis is commonly found in mammalian, including mice, and has been associated with inflammatory chronic diseases, such as leprosy, tuberculosis and rheumatoid arthritis, due to persistent high plasma concentration of SAA, a conserved protein. Leishmanasis are chronic diseases; however, the amyloidosis associated to them is rarely reported in the human being. Nevertheless, the association of leishmaniasis and amyloidosis has been described in the animal model during the course of infection. Mice experimentally infected by Leishmania amanozensis may present, after six months of infection, amyloid deposition in the liver, the spleen and less frequently in the ovaries. Macroscopically, these organs presented a whitish yellow-coloration diffusely distributed in the organ parenchyma. Histologicaly, the amyloid deposition is observed mainly among hepatocytes, in marginal zone of the spleen or in the renal glomerular tufts.

Proteins are found in all cells and carry out a variety of important cellular functions. Folding and unfolding are crucial ways of regulating biological activity and targeting proteins to different cellular locations. Failure to fold correctly, or to remain correctly folded, will therefore give rise to the malfunctioning of living systems and hence to disease (Dobson, 2003).

The largest group of misfolding diseases, which include numerous neurodegenerative disorders and the amyloidosis, originates from the conversion of specific proteins from their soluble functional states into stable, highly ordered, filamentous protein aggregates, known as amyloid fibrils (Uversky, 2003)

In accordance to Xue et al. (2010), the time course of amyloidogenesis and the cellular responses to the presence of amyloid fibrils depends on the extent of fibril fragmentation and that length, width and surface area of amyloid fibrils may play important roles in the mechanism of amyloid deposition.

The term amyloid was coined by the pathologist Virchow, in 1854, to describe an extracellular material found in the liver during the necroscopic exam. This term was used 
because when this affected organ was treated with an iodine-sulfuric acid test, it turned blue, a positive test for starch .

It has been described 27 amyloid protein in human being and at least 9 in animal (Sipe et al., 2010). This protein in histological sections stained by hematoxylin has an amorphous hyaline appearance and when it stained by red Congo and viewed by conventional polarized light the amyloid protein present a green birefringence. The amyloid is not a unique protein presented in tissue deposition it comprises substance such as glicosaminoglycans, substance $\mathrm{P}$ and amyloid protein.

Based on the distribution of the amyloid, amyloidosis is classified in systemic and localized. The systemic amyloidosis are classified in four types: AA amyloidosis, AL amyloidosis, B2 microglobulin and ATR amyloidosis.

AA amyloidosis, in both animals and human, is associated with long-standing chronic infections or inflammatory reaction. In animals is more frequent in bovine suffering from mastitis, traumatic reticuloperintonitis, metritis and pododermatitis (Elitok et al., 2008). This type of amyloidosis is characterized by high concentration in the blood stream of SAA.

SAA is an acute phase protein serum amyloid A produced mainly hepatocytes, has a molecular weight of approximately $12-14 \mathrm{kD}$ and plays a role in reparation of tissue damaged by the inflammatory response. Can be proteolytically processed into an Nterminal cleavage product of approximately 44 to 100 residues that is deposited as amyloid in vital organs, which under normal conditions, all of the SAA is completely degraded. The deposition of this substance lead to cellular dysfunction and the clinical signs depend on the affected organs (Elimova et al., 2009; Sandri et al., 2008).

\section{Amyloidosis $x$ Leishmaniasis}

Leishmaniasis are infectious and parasitic diseases that affect animals and human beings, caused by protozoan parasites of the Leishmania species. The genus Leishmania comprises protozoa parasites with a digenetic life cycle, living alternately in vertebrates hosts and phebotomine sandflies. The insect is responsible for transmission of parasites of a mammalian to another (Asfhord, 2000). In vertebrate hosts, Leishmania survives as amastigotes form, primarily in macrophages, that are ingested when the female sandfly takes a blood meal from an infected host. Several clinical syndromes are subsumed under the term leishmaniasis: most notably visceral, cutaneous, and mucosal leishmaniasis, which result from replication of the parasite in macrophages in the mononuclear phagocyte system, dermis, and naso-oropharyngeal mucosa, respectively (Herwaldt, 1999).

AA amyloidosis is rarely described in naturally infection by Leishmania spp. However several author have been reported the occurrence of this disease in experimental infection (Carvalho et al., 2008; Barbosa-Santos et al., 1984).

Even in murine model it has been observed that AA amyloidosis occur only in some strains of mice. In different experiment where DBA/2, Swiss, BALB/c, C57BL/ 6 female were infected with promastigote and amastigote of L. amanozensis just Swiss and C57BL/ 6 presented amyloidosis in the course of the infection (Cupolillo et al., 1998 Carvalho et al., 2008). Several hypotheses have been postulated to explain why a minority of patients displayed AA amyloidosis during chronic inflammatory infection. In accordance to Westermark and Westermark al., 2009, the individuals probably have 
deficient degradation system for aggregated proteins or they had received one or several nucleation or seeding factors. Even C57BL/6 mice, an inbred strain, challenged with that same inoculum some animals did not display AA amyloidosis after the long term after the infection. Studies show that Swiss male mice were more prone to AA amyloid deposition than female. This may be one of explanation why not all C57BL/6 mice displayed amyloidosis. On the other hands, BALB/c mice did not present amyloid deposition probably due to high susceptibility to L. amazonensis, what lead to generalized disease at 60 or 90 days post infection. Thus, several factors such as sex, duration and type of infection and polymorphism can contribute to onset of AA amyloidosis (Shtrasburg et al., 2004; van der Hilst, 2011).

The pathogenesis of leishmaniasis is related to the genetic background of the host and the Leishmania species and the modulation of T-cell immune response can be influenced by the infective Leishmania species as described by Silveira et al. (2009), since the clinical manifestation of cutaneous depends on both the host immune response and the specie of Leishmania involved.

All mice that presented amyloid deposition develop palpable lesion in skin in the delayed phase of the infection, which allowed that this animals were maintained for long period after infection. When mice presented primary lesion they were euthanatized. The necropsy exam revealed that liver, spleen and kidney presented pale and enlargement. The other organs did not present macroscopic lesions.

The histological sections stained by haematoxylin and eosin showed the liver presented an inflammatory reaction in portal area and deposition of a hyaline and amorphous substance among the hepatocytes. The same substance was seen in renal corpuscle and in the splenic marginal zone. In additional, C57BL/ 6 mouse showed a diffuse amyloid deposition in the ovary. The Congo red staining revealed that the amorphous substance presented in the sampled organs had a yellow-green birefringence under polarized light, confirming the occurrence of amyloid protein deposition. This dye presents a linear molecule that permits that hydrogen bonding of its azo and amino radicals to hydroxyls radicals of amyloid protein, which explain the birefringence under polarized light.

Amyloid A fibril protein in secondary amyloidosis is designated as AA protein, which is derived from the precursor protein known as serum amyloid A, or SAA. SAA protein is an acute-phase reactant produced by liver cells in response to macrophage-derived inflammatory cytokines such as interleukin 1, interleukin 6 and tumor necrosis factor-alpha. A major factor responsible for the development of AA amyloidosis is the increased synthesis and subsequent degradation of the precursor protein SAA1 under chronic inflammatory conditions (Ray et al., 2006). Approximately $45 \%$ of systemic amyloidosis reported in the literature is AA amyloidosis.

Amyloidosis has been described in spleen and liver of dogs naturally infected with $L$. infantum (Bely and Apathy, 2000; Poli et al., 1991; George et al., 1976). In hamsters, this pathology has been reported in adrenal gland (Novoa et al., 1990) in mice amyloidosis is most common in liver (Figure 1), spleen and kidney (Figure 2) Here, inflammatory infiltrates were observed in both medullary and cortical regions, however amyloidosis depositions were not demonstrated, suggesting passage of parasitic antigen though these organs but without evidence of parasites. Previous studies showed that Swiss mice infected with $L$. amazonensis amastigotes had developed amyloidosis in spleen, liver, and kidney 10 months post-infection (Barbosa-Santos et al., 1984). 


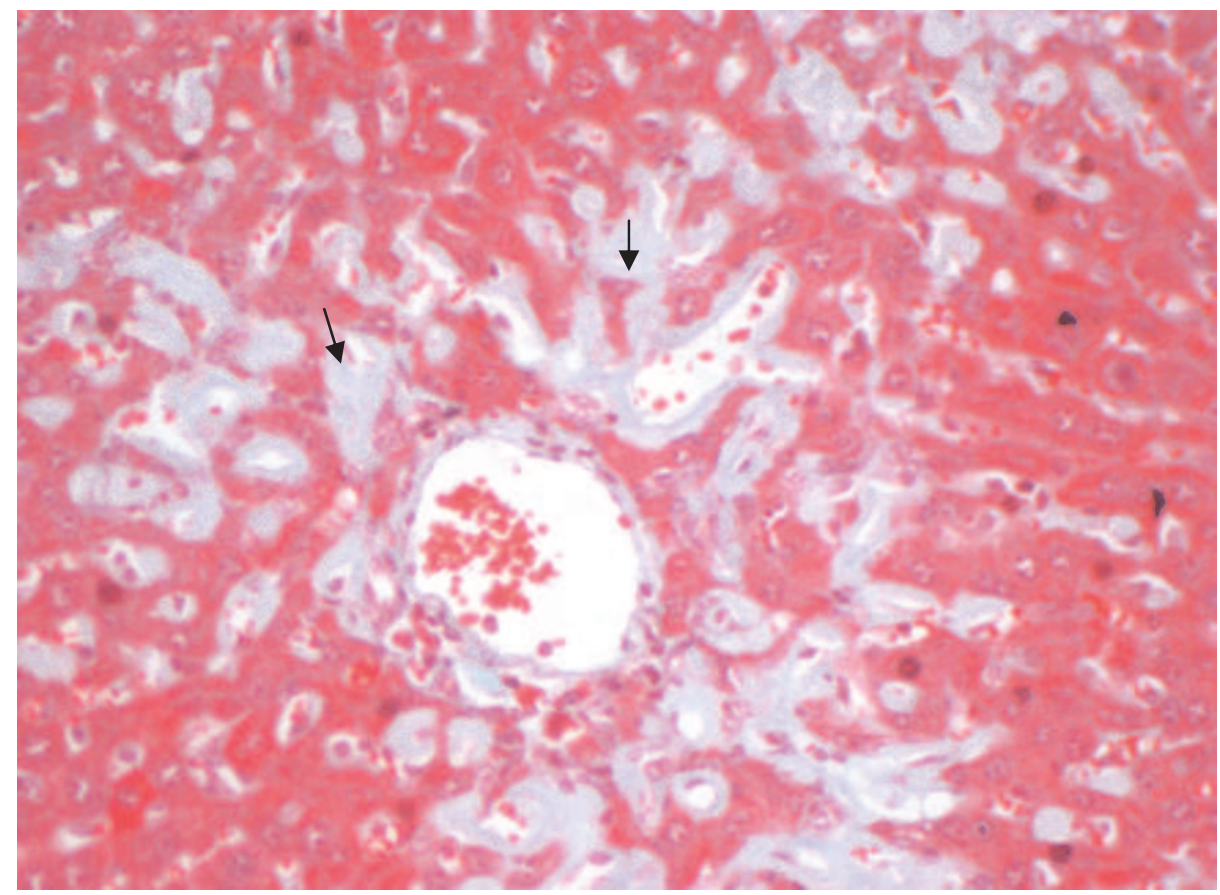

Fig. 1. Liver - Amyloidal deposits among hepatocytes cells (arrows) - Gomori Trichrome Stain. Scale bar $100 \mu \mathrm{m}$. 


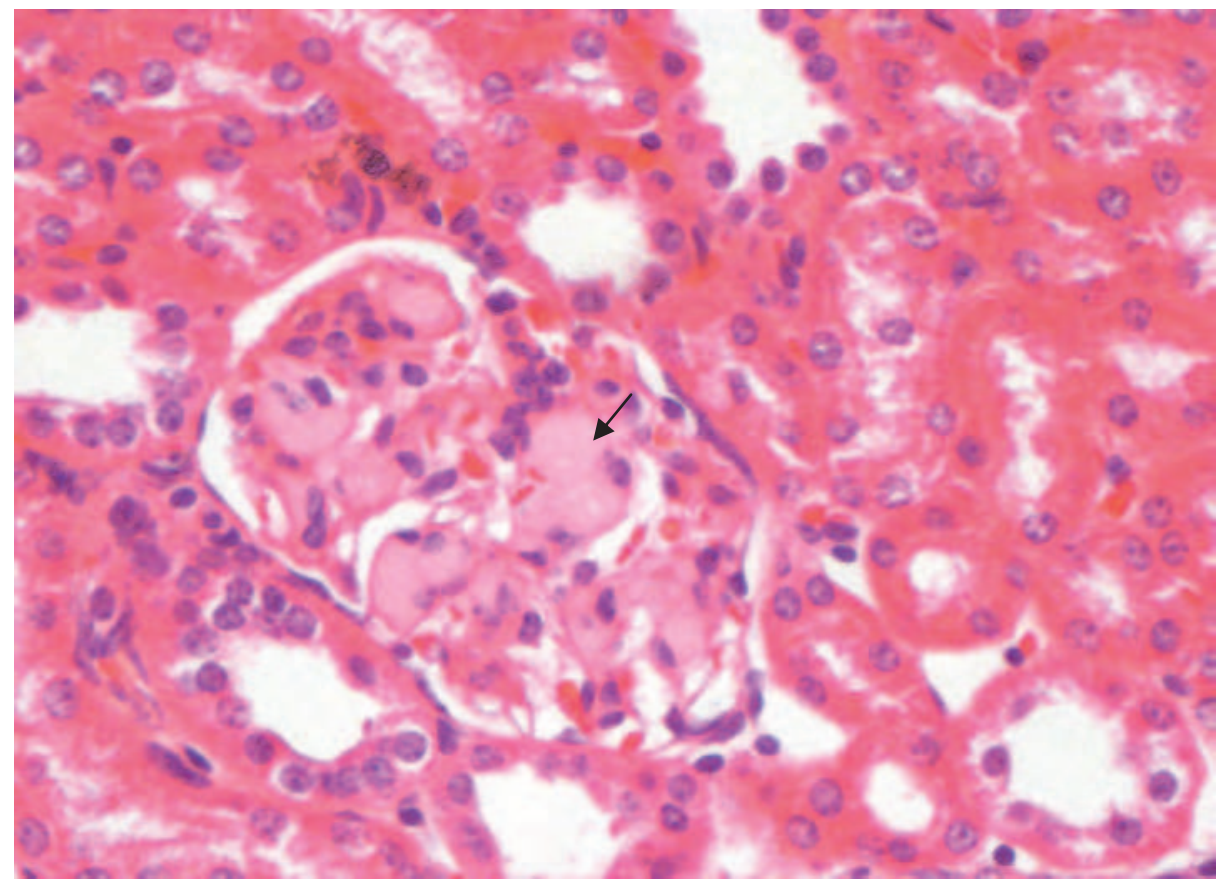

Fig. 2. Kidney - Amyloidal deposits in the glomerular tuft (arrows) - Hematoxylin-Eosin. Scale bar $100 \mu \mathrm{m}$

\subsection{Conclusions remarks}

In murine model, the persistence of the Leishmania infection lead to amyloid deposition, which may impair the function of several organs, including, liver, spleen, kidney and ovary. The tecidual damage is caused by several factor.

\section{Acknowledgment}

Dr. Abreu-Silva and Dr Calabrese hold a research fellowship from the Brazilian National Research Council (CNPq), Brazil.

\section{References}

Ashford, R. W.(2000). The leishmaniases as emerging and reemerging zoonoses. International journal for parasitology, Vol. 30, N. 12-13, (November 2000), pp. 1269-1281, ISSN 1879-0135

Barbosa-Santos E.G. , Gonçalves da Costa, S. C., and Alencar, A., Amyloidosis in experimental tegumentary leishmaniasis in mice, The American Journal of Tropical Medicine and Hygiene 33 (1984), pp. 1270-1271, ISSN 0002-9637 
Bely, M. and Apathy, A., Histochemical and immunohistochemical differential diagnosis of amyloidosis - a brief illustrated essay and personal experience with Romhanyi's method, Amyloid 7 (2000), pp. 212-217, ISSN 1350-6129

Carvalho, L. O.; Calabrese, K. da S.; da Costa, S. C.; Mendes, V. G.; da Silva, A. P.; Barros, A. C.; Melo, S. de A. \& Abreu-Silva, A. L.(2003). Leishmania (Leishmania) amazonensis: experimental cutaneous leishmaniasis associated with systemic amyloidosis in mice. Experimental Parasitology, Vol. 120, N. 1, (June 2008), pp. 123125, ISSN 0014-4894

Cupolillo, E.; Momen H. \& Grimaldi, G. Jr. (1998). Genetic diversity in natural populations of New World Leishmania. Memórias do Instituto Oswaldo Cruz, Vol. 93, N. 5, (September/October 1998), pp. 663-668, ISSN 0074-0276

Dobson C. M.(2003). Protein folding and misfolding. Nature, Vol 426, N. 6968, (December 2003), pp. 884-890, ISSN 0028-0836

Elimova, E.; Kisilevsky, R. \& Ancsin, J. B.(2009). Heparan sulfate promotes the aggregation of HDL-associated serum amyloid A: evidence for a proamyloidogenic histidine molecular switch. FASEB, Vol. 23, N. 10, (June 2003), pp. 3436-3448, ISSN 0892-6638

Elitok, O. M. \& Unver, O.(2008). Renal amyloidosis in cattle with inflammatory diseases. Journal of Veterinary Internal Medicine, Vol. 22, N. 2,(February 2008), pp. 450-455, ISSN 1939-1676

George, J.W., Nielsen, S.W., Shiyeley, J.N., Hopek, S. and Mroz, S. , Canine leishmaniasis with amyloidosis, Veterinary Pathology 13 (1976), pp. 365-373, ISSN 0300-9858

Herwaldt, B. L.(1999). Leishmaniasis. Lancet, Vol. 354, N. 9185, (October 1999), pp. 11911199, ISSN 1040-6736

Hubng-Hsu, H; De-Feng, H.; Cheng-Hwai, T.; Cheng-Hsi, S.; Tung-Ping, S.; Hunf-Chieh, C.; Shyh-Haw, T.; Han-Chich, L.; Jaw-Ching, W.; Shou-Dong, L. \& Chien-Wei, S.(2010). Systemic Amyloidosis Manifesting as a Rare Cause of Hepatic Failure. Journal of the Chinese Medical Association, Vol.75, N.3, (Mach 2010), pp. 161-165, ISSN 1726-4901

Kleiner, E. \& Benson, M. D.(1980). Synthesis and secretion of serum amyloid protein A (SAA) by hepatocytes in mice treated with casein. The Journal of Immunology, Vol. 124, N. 2, pp. 495-499, ISSN 0022-1767

Lavatelli, F.; Perlman, D. H.; Spencer, B.; Prokeaeve, T.; McComb, M. E., Théberge, R.; Connors, L. H.; Bellotti, V.; Seldin, D. C.; Merlini, G.; Skinner, M. \& Costello, C. E.(2008). Molecular \& Cellular Proteomics, Vol. 7, N. 8,(May 2008), pp. 1570-15783, ISSN 1535-9484

Martins, R. G.; Roncon-Albuquerque, R. J.; Cabral, R.; Frazão, J. \& Von Hafe, P.(2010). Primary Amyloidosis Associated With Kappa Light Chain Myeloma. Acta Medica Portuguesa, Vol. 23, N. 2,(March/April 2010), pp. 281-284, ISSN 16460758

Monsellier, E.; Ramazzoti, M.; Tadei, N. \& Chiti, F. (2010). A Computational Approach for Identifyng the Chemical Factors Involved in Glycosaminoglycans-Mediated Acceleration of Amyloid Fibril Formation. PLoS ONE, Vol.5, No.11363, (June 2010), p. e11363, ISSN 1932-6203 
Novoa, C., Garcia, P., Rollan, E. and Gonzalez, J.L., Amyloidosis in adrenal glands of hamsters experimentally infected with Leishmania infantum, Histology and Histopathology 5 (1990), pp. 225-229, ISSN 1699-5848

Poli, A., Abramo, F., Mancianti, F.,,Nigro, M.,Pieri, S. and Bionda, A., Renal involvement in canine leishmaniasis. A light-microscopic, immunohistochemical and electronmicroscopic study, Nephron 57 (1991), pp. 444-452, ISSN 0028-2766

Ray,A., Shakya, A.,Kumar, D.,Benson M.D. and Ray, B. K., Inflammation-responsive transcription factor SAF-1 activity is linked to the development of amyloid A amyloidosis, Journal of Immunology 177 (2006), pp. 2601-2609, ISSN 0022-1767

Sandri, S.; Rodriguez, D.; Gomes, E.; Monteiro, H. P.; Russo, M. \& Campa, A.(2008). Is serum amyloid A an endogenous TLR4 agonist?. Journal of leukocyte biology, Vol. 83, N. 5, (February 2008), pp. 1174-1180, ISSN 0741-5400

Shtrasburg, S.; Pras, M.; Dulitzky, M.; Pariente, C.; Gal, R.; Mor, A. \& Livneh, A.(2004). Increased propensity for amyloidogenesis in male mice. Clinical and Experimental Rheumatology, Vol. 22, N. 4, (July-August 2004), pp. 241-246, ISSN 0392-856

Silveira, F. T.; Lainson, R; de Souza, A. A.;Campos, M.B.; Carneiro, L. A.; Lima, L. V.; Ramos, P. K.; de Castro Gomes, C. M.; Laurenti, M. D. \& Corbett, C. E.(2009). Further evidences on a new diagnostic approach for monitoring human Leishmania (L.) infantum chagasi infection in Amazonian Brazil. Parasitology research, Vol.106, N. 2, (November 2009), pp. 367-386, ISSN 0932-0113

Sipe, J. D.; Benson, M. D.; Buxbaum, J. N.; Ikeda, S.; Merlini, G.; Saraiva, M.J. \& Westermark, P.(2010). Amyloid fibril protein nomenclature: 2010 recommendations from the nomenclature committee of the International Society of Amyloidosis. Amyloid, Vol. 17, N. 3-4, (November 2010), pp. 101-104, ISSN 1744-2818

Snow, A. D.; Bramson, R.; Mar, H.; Wight, N. T. \& Kisilevsky, R.(1991). A Temporal and Ultrastructural Relatonship Between Heparan Sulfate Prteogycans and AA Amyloid in Experimental Amyloidosis. Journal of Histochemistry $\mathcal{E}$ Cytochemistry, Vol. 39, N. 10,(May 1991), pp. 1321-1330, ISSN 0022-1554

Steel, D. M.; Rogers, J. T.; DeBeer, M. C.; DeBeer, F. C. \& Whitehead, A. S.(1993). Biosynthesis of human acute-phase serum amyloid A protein (A-SAA) in vitro: the roles of mRNA accumulation, poly(A) tail shortening and translational efficiency. Biochemical Journal, Vol. 291, N. Pt 3, (May 1993), pp. 701-707, ISSN 0264-6021

Shtrasburg, S.; Pras, M.; Dulitzky, M.; Pariente, C.; Gal, R.; Mor, A. \& Livneh, A.(2004). Increased propensity for amyloidogenesis in male mice. Clinical and experimental rheumatology, Vol. 22, N. 4, (July-August 2004), pp. 421-426, ISSN 0392-856X

Strokes, M. I. \& Trickey, R. J.(1973). Screening for neurofibrillary tangles and argyrophilic plaques with Congo Red and polarized light. Journal of Clinical Pathology, Vol.26, N.3, (March 1973), pp. 241-242, ISSN 0021-9746

Uversky V. N.(2003). Protein folding revisited. A polypeptide chain at the foldingmisfolding-nonfolding cross-roads: which way to go?. Cellular and Molecular Life Sciences, Vol. 60, N. 9, (September 2003), pp. 1852-1871, ISSN 1420-682 
van der Hilst, J.(2011). Recent Insights into the Pathogenesis of Type AA Amyloidosis. TheScientificWorld, Vol. 11, (March 2011), pp. 641-650, ISSN 1537-744

Westermark G. T. \& Westermark P.(2009). Serum amyloid A and protein AA: molecular mechanisms of a transmissible amyloidosis. FEBS Letters, Vol. 583, N. 16, (August 2009), pp. 2685-2690, ISSN 0014-5793

Xue, W. F.; Hellewell, A. L.; Hewitt, E. W. \& Radford, S. E.(2010). Fibril fragmentation in amyloid assembly and cytotoxicity. When size matters. Prion, Vol. 4, N. 1, (JanuaryMarch 2010), pp. 20-25, ISSN 1933-6896 


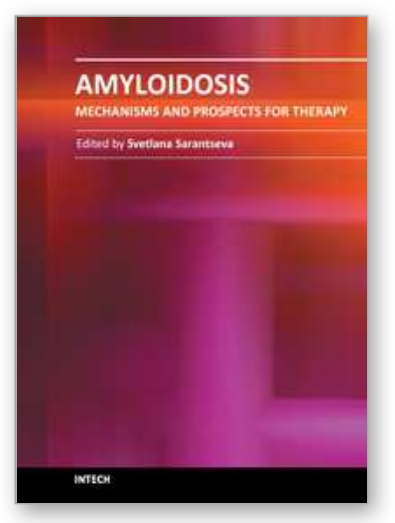

\author{
Amyloidosis - Mechanisms and Prospects for Therapy \\ Edited by Dr. Svetlana Sarantseva
}

ISBN 978-953-307-253-1

Hard cover, 216 pages

Publisher InTech

Published online 22, September, 2011

Published in print edition September, 2011

Amyloidoses are a heterogeneous group of diverse etiology diseases. They are characterized by an endogenous production of abnormal proteins called amyloid proteins, which are not hydrosoluble, form depots in various organs and tissue of animals and humans and cause dysfunctions. Despite many decades of research, the origin of the pathogenesis and the molecular determinants involved in amyloid diseases has remained elusive. At present, there is not an effective treatment to prevent protein misfolding in these amyloid diseases. The aim of this book is to present an overview of different aspects of amyloidoses from basic mechanisms and diagnosis to latest advancements in treatment.

\title{
How to reference
}

In order to correctly reference this scholarly work, feel free to copy and paste the following:

Ana Lucia Abreu-Silva, Gabriel Xavier-Silva, Marlise Neves Milhomem, Mylena Andrea Oliveira Torres and Kátia da Silva Calabrese (2011). Amyloidosis Associated to Leishmania Infection in Murine Model, Amyloidosis - Mechanisms and Prospects for Therapy, Dr. Svetlana Sarantseva (Ed.), ISBN: 978-953-307-253-1, InTech, Available from: http://www.intechopen.com/books/amyloidosis-mechanisms-and-prospects-fortherapy/amyloidosis-associated-to-leishmania-infection-in-murine-model

\section{INTECH}

open science | open minds

\section{InTech Europe}

University Campus STeP Ri Slavka Krautzeka 83/A 51000 Rijeka, Croatia Phone: +385 (51) 770447 Fax: +385 (51) 686166 www.intechopen.com

\author{
InTech China \\ Unit 405, Office Block, Hotel Equatorial Shanghai \\ No.65, Yan An Road (West), Shanghai, 200040, China \\ 中国上海市延安西路65号上海国际贵都大饭店办公楼405单元 \\ Phone: +86-21-62489820 \\ Fax: +86-21-62489821
}


(C) 2011 The Author(s). Licensee IntechOpen. This chapter is distributed under the terms of the Creative Commons Attribution-NonCommercialShareAlike-3.0 License, which permits use, distribution and reproduction for non-commercial purposes, provided the original is properly cited and derivative works building on this content are distributed under the same license. 